\title{
Effect of Cultivar on Quality Attributes of Sweet Potato Fries and Crisps
}

\author{
Nafeesa Ali ${ }^{1}$, Kolawole O. Falade ${ }^{2 *}$, John O. Akingbala ${ }^{1}$ \\ ${ }^{1}$ Food Science and Technology Unit, Department of Chemical Engineering, The University of the West Indies, St. Augustine, Tri- \\ nidad; ${ }^{2}$ Department of Food Technology, University of Ibadan, Ibadan, Nigeria. \\ Email: *kolawolefalade@yahoo.com
}

Received November $20^{\text {th }}, 2010$; revised December $10^{\text {th }}, 2010$; accepted March $10^{\text {th }}, 2011$

\begin{abstract}
Effect of cultivar differences on physical and proximate composition, and sensory attributes of sweet potato fries and crisps were determined. Physicochemical and colour characteristics of sweet potato flours and starches were evaluated using Rapid Visco Analyser and Hunter L a b, respectively. Chroma, colour intensity and hue angle were calculated. Objective and sensory parameters of sweet potato fries and crisps were evaluated. Proximate and pasting properties were typical of sweet potato tubers, flour and starches. Maltose $(0.05 \%-0.08 \%)$, sucrose $(0.05 \%-1.60 \%)$ contents of sweet potato were significantly different $(\mathrm{p}<0.05)$. Amylose and amylopectin contents of sweet potato starches were $19.5 \%-24.6 \%$ and $75.4 \%-80.5 \%$, respectively. Swelling power and solubility were $2.42-2.88$ and $0.11-0.32,5.01$ and $0.02-3.00$ for flours and starches, respectively. Lovers name fries showed significantly better appearance, while Big Red and Black Vine fries showed similar sensory scores. No significant difference occurred in all the sensory attributes of crisps of the sweet potato cultivars.
\end{abstract}

Keywords: Sweet Potato Cultivars; French Fries; Crisps; Starches; Pasting Properties; Sensory Attributes

\section{Introduction}

Sweet potato (Ipomoea batatas L.) is a major economical and healthy food crop in developing countries [1], which is mainly consumed as boiled roots. Although sweet potato is cheaper than other crops, this abundant resource is still poorly utilized. Sweet potato roots can be processed into products with improved characteristics and longer shelf life. The occurrence of natural hybrids and mutations and artificial selection of sweet potatoes have resulted in the existence of large number of cultivars $[2,3]$. These cultivars differ in many of their properties, ranging from the physical appearance and texture of the tuber to structure-function properties of the starch [4]. Orangefleshed sweet potato (OFSP) is among the bio-fortified staples bred for high provitamin A carotenoid content [5]. Besides their role as sources of vitamin A, carotenoids have attracted great interest due to their value as antioxidants which have been related to their capacity to reduce cancer and other degenerative diseases [6,7].

Sweet potatoes are high in energy, dietary fiber, potassium and vitamin $\mathrm{C}$, low in fat and are important sources of the dietary antioxidant $\beta$-carotene [8]. The starch content of the fresh roots can vary from $6.9 \%$ to $30.7 \%$ [9].

${ }^{*}$ Corresponding author.
Starch, the main industrial product of sweet potatoes is used in the manufacture of noodles [10,11], syrup, glucose and isomerized glucose [12], bakery and snack foods [1]. The carbohydrate composition in sweet potato roots greatly affects the eating quality and processing traits [13]. Moreover, the use of sweet potato and products including starch is primarily determined by its physicochemical properties. Pasting behaviour, crystalline structure and gelatinization of sweet potato starches have been investigated [9-11,13].

Sweet potato is becoming increasingly popular as an alternative raw material for the production of French fries [14], and sweet potato chips is gaining wide acceptability too. Sweet potato French fries and crisps are potential nutritional snack foods when produced from cultivars high in provitamin A and ascorbic acid. Some of the advantages of producing different products from sweet potatoes includes greater variety and convenience. The use of the red fleshed sweet potato for the production of French fries and crips would further enhance nutrition of the consumers. Consequently, the objective of this study was to evaluate the effect of cultivar (white and orange fleshed) on the quality attributes of sweet potato fries and crisps. 


\section{Materials and Method}

\subsection{Physical Properties of Sweet Potato}

Three most widely accepted sweet potato cultivars in the Caribbean namely Lovers Name, Big Red, and Black Vine were obtained from the Caribbean Agricultural and Research Development Institute (CARDI), St. Vincent and the Grenadines. The sweet potatoes cultivars were evaluated visually for peel colour, and the length and diameter were measured using a vernier AF1125 Digital Caliper (Model No. 500-196, Serial No. 02231031, Mitutoyo Products, America).

\subsection{Production of Sweet Potato French-Fry}

Sweet potato roots were thoroughly washed with potable tap water and peeled manually with a stainless steel potato peeler. The roots were cut, manually into a Frenchfry strip $(7 \times 1.9 \times 0.64 \mathrm{~cm})$ using a stainless steel knife and deep-fried in soy bean oil (100 g in $2000 \mathrm{~g}$ oil) at $185^{\circ} \mathrm{C}$ for approximately 5 minutes, until light brown colour developed on the strip and bubbling in the oil ceased. Following frying, the samples were spread on an absorbent paper to remove excess oil, air-cooled to ambient temperature, and then packaged in transparent low density polyethylene bags (thickness of $0.06 \mathrm{~mm}$ ), and to prevent moisture loss prior to quality evaluation. Evaluation of quality attributes of sweet potato crisps was performed few hours after preparation.

\subsection{Production of Sweet Potato Crisps}

The sweet potato roots were thoroughly washed in potable tap water and peeled manually with a stainless steel potato peeler. The peeled roots were sliced into discs of $1 \mathrm{~mm}$ thickness using a Hobart slicer (Model 1612 Hobart Corporation, Troy Ohio, USA). The discs were then fried at $185^{\circ} \mathrm{C}$ for approximately 5 minutes $(100 \mathrm{~g}$ in $2000 \mathrm{~g}$ oil), until light brown colour on the crisps developed. Following frying, the fried samples were spread on absorbent paper to remove excess oil and allowed to air cooled to $30^{\circ} \mathrm{C} \pm 2^{\circ} \mathrm{C}$ and then packaged in transparent low density polyethylene bags (thickness of $0.06 \mathrm{~mm}$ ). The bags were sealed with plastic twisters to prevent moisture loss prior to quality evaluation. Evaluation of quality attributes of sweet potato crisps was performed few hours after preparation.

\subsection{Texture Measurements of Sweet Potato FRENCH Fries and Crisps}

The texture of the sweet potato French fries and crisps of Lovers Name, Big Red and Black Vine cultivars were evaluated using a penetrometer Model k95500 (Koehler Instrument Company Inc., Bohemia, NY, USA). Fries and crisps were centered on a metal plate. A blunt probe, diameter $0.5 \mathrm{~cm}$ was released through the sample and the distance moved through the sample recorded from a dial. The texture of the fried sweet potato products of each cultivar was determined in triplicate.

\subsection{Preparation of Sweet Potato Flour}

The sweet potato roots were washed and manually peeled. The peeled sweet potatoes were thinly sliced into $2 \mathrm{~mm}$ thickness (Jangchud et al., 2003) using a Hobart slicer (Model 1612 Hobart Corporation, Troy Ohio, USA), air dried in convective Thelco laboratory oven (Precision, Winchester, VA, USA) at $60^{\circ} \mathrm{C}$ for 24 hours. The dried sweet potato was finely ground using an electric hand mill (Model No 4E, The Straub Company, Hatboro, PA, USA). The flours were packaged in polypropylene Zip$\operatorname{loc}^{\circledR}$ bags, sealed and stored in a refrigerator $\left(5^{\circ} \mathrm{C}-10^{\circ} \mathrm{C}\right)$ until required.

\subsection{Preparation of Sweet Potato Starch}

Clean sweet potatoes roots washed in potable tap water were manually peeled to remove the thin outer skin. The washed tubers were sliced into $2-3 \mathrm{~cm}$ cubes, and blended for 3 - 4 minutes in water $(1: 1 \mathrm{w} / \mathrm{w})$, in a Waring blender (Serial No. 544011; Model No. CB15, 16; Waring Commercial, Torrington, CT), at a low speed setting. The resulting slurry was then passed through fine muslin to separate cell debris and the translucent suspension [15]. The filtrate was collected, washed with potable tap water and filtered three times through fine muslin, using a total of $7.0 \mathrm{~L}$ of water. The filtrate was then allowed to settle for $30 \mathrm{~min}$ to $1 \mathrm{hr}$. The supernatant was decanted and the settled starch was removed from the vessel unto paper towel-lined perforated metal trays, then oven-dried at $50^{\circ} \mathrm{C}$ for $24 \mathrm{hr}$. The dried starch was finely ground using a mortar and pestle, packaged in polypropylene Ziploc ${ }^{\mathbb{B}}$ bags, sealed, and stored at $5^{\circ} \mathrm{C}-10^{\circ} \mathrm{C}$ until needed.

\subsection{Colour Determination}

Sweet potato flour and starch, from each cultivar, were placed into Petri dishes (10 cm diameter; $2 \mathrm{~cm}$ depth), and their colour was evaluated with Hunter L, a, b, parameters using a Chroma meter (Model No CR-210/CR310/CR-410, Konica Minolta Sensing, Inc., Japan) standardized against Perfect Reflecting Diffuser Plate (standard No. C2-40524) $\left(\mathrm{X}_{\mathrm{CIE}}-79.53, \mathrm{Y}_{\mathrm{CIE}}-81.54, \mathrm{Z}_{\mathrm{CIE}}-\right.$ 97.03). Hunter $L$ values range from 100 (white) to 0 (black), a values range from $+\mathrm{a}$ (green) to $-\mathrm{a}$ (red), and $\mathrm{b}$ values range from $+b$ (yellow) to $-b$ (blue). Average of the readings were computed and reported. Chroma $(\Delta \mathrm{C})$, colour intensity $(\Delta \mathrm{E})$ and hue angle $(\mathrm{H})$ were calculated using Equations (1), (2) and (3), respectively. 


$$
\begin{gathered}
\mathrm{E}=\sqrt{(\mathrm{L})^{2}+(\mathrm{a})^{2}+(\mathrm{b})^{2}} \\
C=\sqrt{(\mathrm{a})^{2}+(\mathrm{b})^{2}} \\
\mathrm{H}=\operatorname{Tan}^{-1}(\mathrm{~b} / \mathrm{a})
\end{gathered}
$$

\subsection{Proximate Composition}

Moisture content of the fresh tuber and flour of the sweet potato cultivars was determined according to the method of AACC [16]. Protein (nitrogen) content of sweet potato tuber and flour of each cultivar was determined according to the method of AACC (2000 Method 46-11A) using the Vapodest 20 protein Analyzer (serial No. 004667, Gerhart, GmbH \& Co KG, Konigswinter, Germany). Crude protein was calculated on dry weight basis as $\mathrm{N} \times$ $6.25 \%$. Fat content of sweet potato flour was determined by AACC Method 30 - 10 [16], by extracting $2 \mathrm{~g}$ (dwb) of flour with ether $\left(64^{\circ} \mathrm{C}\right)$. Ash content of sweet potato flour samples was determined, by incinerating flour samples $(3-5 \mathrm{~g})$ in a muffle furnace at $550^{\circ} \mathrm{C}$ for $5 \mathrm{hr}$, then weighing after cooling in a desiccator [16].

\subsection{Determination of Amylose and Amylopectin Contents}

Amylose content of starch and flour samples of sweet potato cultivars was determined in triplicate by colorimetric method [16]. The starch-iodine complex developed at pH 4.5 - 4.8 in acetate buffer was read in a Helios spectrophotometer (Pye Unicam, Germany) at $620 \mathrm{~nm}$. The blue colour developed was read against a standard amylose curve plotted from solutions with concentrations of $0-100 \mathrm{mg}$ amylose $/ 100 \mathrm{~mL}$ water. The amylopectin content was calculated by subtracting the amylose content from $100 \%$.

\subsection{Determination of Reducing and Non-Reducing Sugars}

Reducing and non-reducing sugars of sweet potato flour were determined by AACC [16] method, using Ferriccyanide-Maltose-Sucrose Conversion tables. Reducing sugars were expressed as mg maltose $/ 10 \mathrm{~g}$ flour and starch, and non-reducing sugar as mg sucrose/10g flour and starch, which were converted to percentages.

\subsection{Determination of Swelling Power and Solubility}

Swelling power and solubility of sweet potato starch and flour were determined in triplicate, by heating starchwater slurry $(0.35 \mathrm{~g}$ starch/flour in $12.5 \mathrm{~mL}$ distilled water) in a water bath at $60^{\circ} \mathrm{C}$ for 30 minutes, with constant agitation [17]. The slurries were centrifuged at $1000 \mathrm{~g}$ for 15 minutes, the supernatant was removed, and the soluble material was isolated by evaporation of the liquid at $100^{\circ} \mathrm{C}$ for 20 minutes. The weight of the dried soluble material was used to calculate the starch solubility. The swelling power was obtained by weighing the amount of residue from the centrifugation and then calculating the amount of water absorbed by the starch, as percent weight increase.

\subsection{Determination of Pasting Properties}

Pasting properties were determined using in a Rapid Visco Analyser (Serial No. 2031531, Model RVA-4, Newport Scientific Pty. Ltd., Warriewood, Australia). A suspension of $10 \%$ starch and $15 \%$ flour (dry weight basis) in distilled water was heated from $30^{\circ} \mathrm{C}$ to $95^{\circ} \mathrm{C}$ with constant stirring at $160 \mathrm{rpm}$. The sample was held at $95^{\circ} \mathrm{C}$ for six minutes (breakdown), and then cooled to $50^{\circ} \mathrm{C}$ (setback). Total cycle time was thirty-eight minutes. Pasting curves were obtained for the starch and flour samples of each sweet potato cultivar. Visco-amylograph profiles were determined as follows: the pasting temperature was defined as the temperature at which an increase in viscosity was first detected by the instrument [18]; peak viscosity was defined as the equilibrium point between swelling and polymer leaching or breakdown; trough was defined as the lowest viscosity; final viscosity was defined as the viscosity of the sample at the end of the cycle period; setback was defined as the difference between final viscosity and peak viscosity; peak time was defined as the time the peak viscosity occurred.

\subsection{Determination of the Sensory Evaluation and Consumer Acceptance}

Sweet potato fries and crisps of each cultivar were subjected to sensory evaluation by a 45-member, semitrained panel made up of individuals who were familiar with the quality attributes of the products and consume then regularly. Panelists evaluated coded sweet potato French fries and crisps samples presented in a random order for appearance, taste, texture and overall acceptability using a 5 -point hedonic scale $(5=$ like extremely, 4 = like, $3=$ neither like nor dislike, $2=$ dislike, $1=$ dislike extremely).

\subsection{Statistical Analysis}

Data were analysed using the Statistix for Windows ${ }^{\circledR} 2.2$ Program. Duncan's (Duncan, 1965) multiple range test was used to separate significantly different mean scores. Significant difference was established at $\mathrm{p} \leq 0.05$. 


\section{Results and Discussion}

\subsection{Proximate Composition of Peeled Raw (Unprocessed) Sweet Potato}

Table 1 shows the physical and proximate characteristics of sweet potato cultivars used in this study namely Black Vine, Big Red and Lovers Name.

The external colour of Black Vine, Big Red and Lovers Name tubers were light red burgundy, light red burgundy and light brown, while their flesh colours were white, white and orange, respectively. The chemical composition of the raw sweet potato cultivars is presented in Table 1. Moisture contents of the Black Vine, Big Red and Lovers Name cultivars were $72.1 \%, 69.1 \%$ and $68.1 \%$ respectively. Moisture content was significantly different ( $\mathrm{p} \leq 0.05)$ but showed low variation. Bradbury and Holloway [19] indicated that differences in moisture contents of sweet potato cultivars are due to such factors such as cultivar, location, climate, soil type, incidence of pests and diseases, and cultivation practices.

The protein contents of Black Vine (2.5\%), Big Red (2.1\%) and Lovers Name cultivars $(2.1 \%)$ were statistically similar $(\mathrm{p} \leq 0.05)$ and in agreement with previously reported values of $5 \%(\mathrm{dwb})$ [1], 4.91\% - 8.44\% [20], $1.85 \%$ to $2.00 \%$ [21] and 0.49 to $2.24 \%$ [22]. Aina et al. [2] reported low protein and fat contents for 21 Caribbean sweet potato cultivars. Crude protein content of sweet potato tubers is not evenly distributed throughout the root; it is slightly higher at the proximal end than at the distal end, and higher in the outer layers close to the skin [21]. Ash content of Lovers Name, Black Vine, and Big Red are 2.8\%, 2.4\% and 2.1\%, respectively (Table 1). The ash content (dwb) of sweet potato was reported as $3 \%-4 \%$ [1] and 1.55 to $2.04 \%$ [23]. Woolfe [1] also reported that the ash content of the sweet potato peel is higher than that of the flesh. Makki et al. [23] showed that the average ash concentrations in the peel and the flesh of two Egyptian cultivars were $4.1 \%$ and $4.6 \%$ (dwb) respectively. Ash content of Lovers Name, Black Vine and Big Red appeared low because the tubers were peeled. Minerals of raw sweet potatoes include calcium, phosphorous, magnesium, sodium, potassium, iron, copper and zinc [12].

Lovers Name, Black Vine and Big Red flours showed significantly different $(p \leq 0.05)$ sucrose contents of
$1.6 \%, 0.80 \%$ and $0.05 \%$ (dry weight basis), respectively. Also, maltose content of Lovers Name, Black Vine, and Big Red were $1.7 \%, 0.05 \%$ and $0.08 \%$, respectively. Maltose content of Big Red and Black Vine cultivars were statistically similar while the Lovers Name was significantly higher $(\mathrm{p} \leq 0.05)$ than these (Table 1). Generally, sugar content of Lovers Name was double that of Big Red and Black Vine tubers. The significance of this is that various cultivars have different sweetness when cooked or used for culinary or manufacturing purposes. High sugar content may also have dietary implications especially with the diabetic.

The composition of sweet potato starch is presented in Table 2. The low moisture content of Lovers Name $(8.9 \%)$, Black Vine (11.5\%) and Big Red (9.04\%) was an evidence of good drying regime. Moisture content of Black Vine was significantly higher than Big Red and Lovers Name. The moisture content of sweet potato starch was reported as $11 \%-17 \%$ [9] and $9.8 \%-15.3 \%$ [14], and was dependant on the process used for drying. The maximum moisture content for safe storage of starch is $13 \%$ [24]. Higher levels of moisture could lead to microbial spoilage and subsequent deterioration in quality. It is expected that the starches produced in this study would have a low susceptibility to spoilage and deterioration in quality due to microbial activity, with proper storage in moisture proof polyethylene packaging materials.

The starches produced from Lovers Name, Black Vine and Big Red cultivars were prime starches with protein contents of $0.10 \%, 0.06 \%$ and $0.05 \%$, respectively. Davies [25] reported that potato starch should contain less than $0.1 \%$ protein. Amylose contents of $19.5 \%$, $21.2 \%$ and $24.6 \%$, (Lovers Name, Black Vine and Big Red starches) were within the range reported by Wankhede and Sajjan [26], 20.5\% - 25.5\%. A wider amylose content range of $8.5 \%-38 \%$ had been reported in an earlier study by Rasper [27], indicating the variation in the utilization properties of sweet potato starches with respect to their pasting and other textural properties. O'Connor et al. [28] classified sweet potatoes into waxy and floury types. Sweet potatoes with as low as $8.5 \%$ amylose might fall into the "waxy" classification. O'Connor et al. [28] determined waxy sweet potatoes to be higher in sugar and to hold their shape after cooking, and suggested that waxy sweet potatoes should not used for

Table 1. Physical and proximate characteristics of fresh sweet potato cultivars.

\begin{tabular}{cccccccc}
\hline Cultivar & Colour & Shape & Moisture & Protein & Ash & Maltose & Sucrose \\
\hline Black Vine & LBR & Spindle oval & $69.1^{\mathrm{a}}$ & $2.1^{\mathrm{a}}$ & $2.4^{\mathrm{a}}$ & $0.05^{\mathrm{b}}$ & $0.80^{\mathrm{b}}$ \\
Big Red & LBR & Light red & $68.1^{\mathrm{a}}$ & $2.1^{\mathrm{a}}$ & $2.1^{\mathrm{a}}$ & $0.08^{\mathrm{b}}$ & $0.05^{\mathrm{c}}$ \\
Lovers Name & LB & Spindle oval & $72.1^{\mathrm{a}}$ & $2.5^{\mathrm{a}}$ & $2.8^{\mathrm{b}}$ & $1.7^{\mathrm{a}}$ & $1.6^{\mathrm{a}}$ \\
\hline
\end{tabular}

Means in a column with similar superscripts are significantly different $(\mathrm{p}<0.05)$. LBR: Light red burgundy, LB: Light brown. 
Table 2. Composition of sweet potato starches from different cultivars.

\begin{tabular}{cccccc}
\hline Cultivars & Moisture & Protein & Ash & Amylose & Amylopectin \\
\hline Black Vine & $11.5^{\mathrm{a}}$ & $0.06^{\mathrm{ab}}$ & $2.4^{\mathrm{ab}}$ & 21.2 & 78.8 \\
Big Red & $9.0^{\mathrm{b}}$ & $0.05^{\mathrm{b}}$ & $2.1^{\mathrm{b}}$ & 24.6 & 75.4 \\
Lovers Name & $8.9^{\mathrm{b}}$ & $0.10^{\mathrm{a}}$ & $2.8^{\mathrm{a}}$ & 19.5 & 80.5
\end{tabular}

Means in a column with similar superscripts are significantly different $(\mathrm{p}<$ $0.05)$.

French fries, since sugar undergoes non-enzymatic browning. However, cultivars with high sugar content may be considered for French fries if lower pre-frying temperatures $\left(<175^{\circ} \mathrm{C}-185^{\circ} \mathrm{C}\right)$ would be used [28].

\subsection{Hunter $L$ a b Colour Evaluation of Sweet Potato Flours}

Hunter L a b values presented in Table 3 shows that colours of the sweet potato flours were significantly different $(\mathrm{p} \leq 0.05)$. Black Vine flour was significantly lighter $(\mathrm{L}=79.9)$ than Lovers Name $(\mathrm{L}=78.0)$ and Big Red $(L=72.2)$ flours. The deep orange colour of the Lovers Name tuber was confirmed by its higher $a$ and $b$ values compared to Big Red and Black Vine cultivars. Higher $+\mathrm{a}$ and $+\mathrm{b}$ values which indicated yellow-orange colour in Lovers Name cultivar may have been due to the presence of carotenoids pigments. Positive correlation has been established between all-trans- $\beta$-carotene content and a value of seven different orange fleshed sweet potato varieties $[1,29]$. Also, orange- and yellow-fleshed cultivars recorded higher total carotenoid, $\beta$-carotene, and $\beta$-carotene-5,6-monoepoxide contents than cream- and white-fleshed cultivars [30]. It has been reported that Beta-carotene, a major precursor of Vitamin A, serves as an important nutritional component in foods, as [31] and that it has anti-cancer, anti-aging, and anti-ulcer properties, due to their antioxidative activity [1]. Lovers Name Cultivar showed orange pigmentation, consequently, it should contain higher amount of beta-carotene and a better source of vitamin A precursor, than the Black Vine and Big Red cultivars.

Sweet potato flour indicated lower $\mathrm{L}$ values than the starch showing the darker colour of the flour, latex, sugar and pigments during extraction and washing of starch may have affected it brightness. The starches showed higher $\mathrm{L}$ values than the flours because the pigments were washed off during preparation of the starches. Results showed that a value decreased from +13.0 in Lovers Name flour to -2.1 in the starch. Flours also recorded higher $b$ values than the starches, also indicating a higher intensity of yellow colour in the flours. Decreased a and $\mathrm{b}$ values from flour to starch indicated loss of yellow and red colours. This is a positive indication since starches
Table 3. Colour parameters of peel, flesh, flour and starch of sweet potato cultivars.

\begin{tabular}{ccccccc}
\hline Cultivars/Products & L & $\mathrm{a}$ & $\mathrm{b}$ & $\mathrm{C}$ & $\mathrm{E}$ & Hue angle \\
\hline Peel & & & & & & \\
Black Vine & 34.1 & 13.3 & 4.2 & 13.9 & 36.8 & 16.7 \\
Big Red & 36.3 & 15.8 & 5.7 & 16.8 & 40 & 21.8 \\
Lovers Name & 47.4 & 12.1 & 16.6 & 20.5 & 51.7 & 54.5 \\
Flesh & & & & & & \\
Black Vine & 79.2 & 1.3 & 14.7 & 14.8 & 80.6 & 84.9 \\
Big Red & 79.7 & -1.8 & 18.7 & 18.8 & 81.9 & -84.5 \\
Lovers Name & 62.5 & 27.8 & 29.6 & 40.6 & 74.5 & 47.7 \\
Flour & & & & & & \\
Black Vine & $79.9^{\mathrm{a}}$ & $-1.8^{\mathrm{a}}$ & $14.3^{\mathrm{b}}$ & 14.4 & 81.2 & -82.8 \\
Big Red & $78.0^{\mathrm{b}}$ & $-1.8^{\mathrm{a}}$ & $13.0^{\mathrm{c}}$ & 13.1 & 79.1 & -82.1 \\
Lovers Name & $72.2^{\mathrm{c}}$ & $13.0^{\mathrm{b}}$ & $27.3^{\mathrm{a}}$ & 30.2 & 78.3 & 64.5 \\
Starch & & & & & & \\
Black Vine & $89.8^{\mathrm{b}}$ & $-2.6^{\mathrm{c}}$ & $2.9^{\mathrm{c}}$ & 3.9 & 89.9 & -47.7 \\
Big Red & $91.1^{\mathrm{a}}$ & $-2.5^{\mathrm{b}}$ & $2.7^{\mathrm{c}}$ & 3.7 & 91.2 & -47.7 \\
Lovers Name & $88.6^{\mathrm{c}}$ & $-2.1^{\mathrm{a}}$ & $6.0^{\mathrm{a}}$ & 6.4 & 88.8 & -71.0 \\
\hline
\end{tabular}

Means in a column with similar superscripts are significantly different $(\mathrm{p}<$ $0.05)$.

are supposed to be white. The simplified starch extraction method of this study can further be enhanced to remove more pigments by introducing a solvent-washing step which removes pigments, latex and sugars. This step however would have cost and disposal implications.

\subsection{Swelling Power and Solubility}

The swelling power and solubility of flour and starch samples from Black Vine, Big Red and Lovers Name cultivars are presented in Table 4. The swelling power of starches of the cultivars was higher than swelling power the flours due to the presence of other components in the flours [18] which diluted the starch concentration in the slurry. There have been reports that solutes such as sugars and salt suspensions lower the swelling of starch granules either by competing with the granules for the available moisture or by other mechanisms $[32,33]$. Solubility of Lovers Name flour may have been greatest because of its higher content of soluble sugar and pigment compounds compared to Big Red and Black Vine flours. The solubility of the sweet potato flours of Lovers Name, Big Red and Black Vine was higher than the starches. Difference in swelling power and solubilities of starchy materials can be attributed to starch content, the presence 
of impurities (e.g. protein and lipids) and pre-treatment and processing history [34]. Big Red starch showed lower swelling power than Lovers Name and Black Vine starches probably due to its higher amylose content (Table 4).

\section{Pasting Properties of Flours and Starches}

The pasting properties of starch and flour samples from Black Vine, Big Red and Lovers Name cultivars are presented in Table 5. The pasting temperatures of Black Vine, Big Red and Lovers Name starches were $75.9^{\circ} \mathrm{C}$, $73.05^{\circ} \mathrm{C}$ and $74.7^{\circ} \mathrm{C}$, while pasting temperatures of $80.9^{\circ} \mathrm{C}$, $76.6^{\circ} \mathrm{C}$, and $81.6^{\circ} \mathrm{C}$, respectively. The higher pasting temperature of the sweet potato flour compared to the starch is due to the influence of other components of flour which appeared to have significantly limited starch swelling. Anonymous [35] reported that other components of flour reduced starch concentration, which is reflected in starch viscosity and how early in the cooking cycle, paste viscosity peaks. However, reduction in starch concentration have been more than compensated for in this study by using $50 \%$ more of flour than starch. Therefore the effect of the very low pasting temperatures observed in this study must have been due to the depressing effect of components of the flour (sugars, pigments, proteins, fibre etc) had on swelling. The peak viscosities of Black Vine, Big Red and Lovers Name starches were 334.4, 295.3 and 396.6, while their flours were 48.5, 73.7, and 28.3, respectively. Garcia \& Walter [14] described the peak viscosity as the maximum swelling of the starch granules before disintegration and the equilibrium point between swelling and polymer leaching (breakdown). Differences between the viscosities of the flour and starch are indication of the extent of the influence of other components of the flour on starch swelling. In sweet potato flour, the peak viscosities of the starches have on the average been reduced to $15 \%$ by other components of flour.

The Lovers Name starch recorded the highest peak viscosity while Black Vine starch the lowest. However, Big Red flour showed the highest peak viscosity while the Lovers Name flour recorded the lowest, indicating that the restriction on starch swelling of Lovers Name flour was by its high sugar content (Table 4) among other flour components. The peak time of Black Vine, Big Red and Lovers Name starches, and Black Vine, Big Red and Lovers Name flour were 10.6, 9.8, 10.8, 10.3, 9.9, and 10.3 minutes, respectively. Although the starches and flours showed similar peak time, starches recorded higher maximum viscosities than the flours.

The pasting of sweet potato starch was affected by sugar content. Sugar tenderizes starch gel and reduces paste viscosity because it retards pasting. Sugar attracts and holds water molecules allowing less water to be available to hydrate the starch granules [32]. Due to the hydroscopic nature of sugar, the temperature required for gelatinization is raised thus delaying the process. High sugar content of Lovers Name flour results in higher pasting temperature of $81.6^{\circ} \mathrm{C}$ and lower peak viscosity of 28.3 RVU compared to Black Vine and Big Red flours. The starch molecules do not swell to the extent as they would in the absence of sugar and too much sugar reduces starch viscosity [32,33]. The breakdown (RVU) viscosities of Black Vine, Big Red, Lovers Name starches and Black Vine, Big Red, Lovers Name flours were

Table 4. Swelling power and solubility of sweet potato flours and starches.

\begin{tabular}{ccc}
\hline Cultivar/Product & Swelling power & Solubility \\
\hline Flour & & \\
Black Vine & 2.42 & 0.17 \\
Big Red & 4.60 & 0.11 \\
Lovers Name & 2.88 & 0.32 \\
Starch & & \\
Black Vine & 5.47 & 3.00 \\
Big Red & 5.01 & 0.02 \\
Lovers Name & 5.48 & 0.03 \\
\hline
\end{tabular}

Table 5. Pasting properties of sweet potato flours and starches.

\begin{tabular}{ccccccc}
\hline Pasting property & Black vine flour & Big Red flour & Lovers name flour & Black vine starch & Big Red starch & Lovers name starch \\
\hline Pasting temp $\left({ }^{\circ} \mathrm{C}\right)$ & 80.9 & 76.6 & 81.6 & 75.9 & 73.1 & 74.7 \\
Peak Viscosity (RVU) & 48.5 & 73.7 & 28.3 & 334 & 295.3 & 396.6 \\
$\begin{array}{c}\text { Peak } \\
\text { time (min) }\end{array}$ & 10.3 & 9.9 & 10.3 & 10.6 & 9.8 & 10.8 \\
Trough (RVU) & 3.2 & 1.7 & 7.2 & 121 & 91.4 & 159.8 \\
Breakdown (RVU) & 45.4 & 72.1 & 21.1 & 213.9 & 203.9 & 232.3 \\
Final viscosity (RVU) & 4.5 & 6.2 & 11.5 & 185.3 & 159.1 & 216.7 \\
Setback (RVU) & 1.3 & 4.5 & 4.4 & 64.8 & 67.8 & 56.9 \\
\hline
\end{tabular}


213.9, 203.9, 232.3, and 45.4, 72.1, and 21.1, respectively. The breakdown viscosity provides an estimation of the resistance of the paste to disintegration in response to heat. Throughout the pasting analysis of starch and flour samples, there was a decrease in viscosities, from peak to breakdown, thus showing a breakdown in consistency. The breakdown in consistency occurred due to the application of shear forces to the highly swollen granules which disintegrated, resulting in a decrease in paste viscosity [36]. This showed that intermolecular forces within the granules were weak. Flour samples with low breakdown viscosity showed paste viscosity which thins very rapidly with prolonged cooking [14]. Therefore starch and flour from Black Vine, Big Red and Lovers Name cultivars should not be used in applications in which a prolonged period of high cooking is required.

The average set-back viscosity of Black Vine, Big Red and Lovers Name starches, and Black Vine, Big Red and Lovers Name flours were 64.8, 67.8, 56.9, 1.3, 4.5, and 4.4 , respectively. The starches showed higher set-back values than the flours. Setback, defined as the difference between the final viscosity and the peak viscosity, has been directly related to the amount of amylose leached from the granules [37]. Big Red starch and Big Red flour recorded higher setback viscosity (viscosity at $50^{\circ} \mathrm{C}$ ), while Lovers Name starch and Black Vine flour showed lower values. During the cooking, Black Vine and Big Red cultivars would tend to have stiffer pastes than Lovers Name, due to high amounts of amylose in solution. Similar assertion was stated by Garcia et al. [14].

\subsection{Sensory Evaluation of Sweet Potato Fries and Crisps}

Sensory attributes of sweet potato fries are shown in Table 6. Lovers Name showed significantly better $(\mathrm{p} \leq$ 0.05) appearance than the Black Vine and Big Red fries. There was no difference in the scores of appearance of fries from Black Vine and Big red fries. Higher appearance scores of Lovers Name fries could be due to its orange colour which masks the slight grey colouration of the fries from white-fleshed sweet potato cultivars. The slightly grey tint observed in the fries may have been due to enzymatic browning in which case it might be removed with adequate blanching of the strips prior to frying or the application of bisulphate solution dip into the process. Black Vine and Big red fries recorded significantly better taste scores than the Lovers Name fries, and is indicative of expectation of consumers as to the taste of fries, which are to be bland and probably slightly salty. The texture scores of the fries produced from the cultivars were not significantly different. Overall acceptability scores of Black Vine and Big Red fries were significantly better $(p<0.05)$ than Lovers Name fries maily because of the sweetness of Lover's Name fries.

Table 6 shows the sensory attributes of sweet potato crips. Generally, the appearance, taste, crispiness and overall acceptability scores of the three cultivars were not significantly different. Black Vine crisps showed higher appearance scores than Big Red and Lovers Name crisps. Taste scores of the Big Red and Lovers Name cultivars were slightly higher than Black Vine. However, texture (crispiness) scores of Big Red and Lovers name crisps were lower than Black Vine crisps. Overall, Black Vine crisp showed better acceptance than Big Red and Lovers name crisps as indicated by its higher overall acceptability score.

Table 7 shows the objective (texture) measurement of fries and crisps of Lovers Name, Big Red and Black Vine cultivars measured using a standard penetrometer. Depths of penetration of $8.78,8.22$ and $2.32 \mathrm{~mm}$, for Lovers Name, Big Red and Black Vine cultivars, respectively, were significantly different $(p<0.05)$. Lovers Name fries showed softer texture, compared to the Black Vine and Big Red fries.

\section{Conclusion}

Selected physical and chemical parameteers of three cultivars of sweet potato were determined and related to sensory characteristics of fries and crisps derived from

Table 6. Sensory scores of sweet potato French fries and crisps.

\begin{tabular}{ccccc}
\hline Cultivars/Product & Appearance & Taste & Texture & $\begin{array}{c}\text { Overall } \\
\text { acceptability }\end{array}$ \\
\hline French fries & & & & \\
Black Vine & $2.6^{\mathrm{a}}$ & $3.0^{\mathrm{a}}$ & $2.7^{\mathrm{a}}$ & $2.9^{\mathrm{a}}$ \\
Big Red & $2.6^{\mathrm{a}}$ & $3.0^{\mathrm{a}}$ & $2.8^{\mathrm{a}}$ & $2.9^{\mathrm{a}}$ \\
Lovers Name & $3.1^{\mathrm{b}}$ & $2.7^{\mathrm{b}}$ & $2.8^{\mathrm{a}}$ & $2.7^{\mathrm{b}}$ \\
Crisps & & & & \\
Black Vine & $3.9^{\mathrm{a}}$ & $3.4^{\mathrm{a}}$ & $4.0^{\mathrm{a}}$ & $3.6^{\mathrm{a}}$ \\
Big Red & $3.5^{\mathrm{a}}$ & $3.5^{\mathrm{a}}$ & $3.0^{\mathrm{a}}$ & $3.4^{\mathrm{a}}$ \\
Lovers Name & $3.5^{\mathrm{a}}$ & $3.5^{\mathrm{a}}$ & $3.0^{\mathrm{a}}$ & $3.4^{\mathrm{a}}$ \\
\hline
\end{tabular}

Means in a column with similar superscripts are significantly different $(\mathrm{p}<$ $0.05)$.

Table 7. Textural measurement of of sweet potato French fries and crisps.

\begin{tabular}{ccc}
\hline Cultivar & French fries & Crisps \\
\hline Black Vine & $2.32^{\mathrm{c}}$ & 0 \\
Big Red & $8.22^{\mathrm{b}}$ & 0 \\
Lovers Name & $8.78^{\mathrm{a}}$ & 0 \\
\hline
\end{tabular}


the samples. Physical physicochemical properties of the flours and starches provided information for explaining the behaviour of cultivars during cooking. Fries from Lovers Name showed significantly better $(\mathrm{p}<0.05)$ appearance due to its orange colour, while fries from Black Vine and Big Red fries received significantly better taste scores and had better overall acceptability of Black Vine and Big red fries than fries from Lovers Name because of the lower sugar contents of these cultivars. Generally, the appearance, taste, crispiness and overall acceptability scores of crisps of the three cultivars were not signifycantly different.

\section{REFERENCES}

[1] J. A. Woolfe, "Sweet Potato-Past and Present," In: J. A. Woolfe, Ed., Sweet Potato: An Untapped Food Resource, Cambridge University Press, Cambridge, 1992, pp. 15-40.

[2] A. J. Aina, K. O. Falade, J. O. Akingbala and P. Titus, "Physico-Chemical Properties of Twenty-One Caribbean Sweet Potato Cultivars," International Journal of Food Science and Technology, Vol. 44, No. 9, 2009, pp. 16961704. doi:10.1111/j.1365-2621.2009.01941.x

[3] A. J. Aina, K. O. Falade, J. O. Akingbala and P. Titus, "Physico-Chemical Properties of Twenty-One Caribbean Sweet Potato Starch," Food and Bioprocess Technology. doi:10.1007/s11947-009-0316-6.

[4] T. Zhang and C. G. Oates, "Relationship between Amylase Degradation and Physico-Chemical Properties of Sweet Potato Starches," Food Chemistry, Vol. 65, No. 2, 1999, pp. 157-163. doi:10.1016/S0308-8146(98)00024-7

[5] International Potato Center (CIP) Report, "McKnight Foundation CCRP East African Regional Sweetpotato Project Annual Report," International Potato Center, Nairobi, April 2005-March 2006.

[6] H. Sies and W. Stahl, "Vitamins E and C, $\beta$-Carotene, and Other Carotenoids as Antioxidants," American Journal of Clinical Nutrition, Vol. 62, No. 6, 1995, pp. 1315S1321S.

[7] R. F. Zakaria, "Consumption of Local Fruits and Vegetables Improved Plasma Antioxidant and Immunological Status of Industry Workers Prone to Oxidative Stress," Prosiding Seminar eknologi Pangan, Bogor, 1997, pp. 116122.

[8] V. Hagenimana, E. Carey, J. Low, S. Gichuki, C. Owori, A. Oyunga and J. N. Malinga, "Sweet Potato Post Harvest in East Africa," CIP Sub-Project Annual Progress Report, CIP Library, Lima, 1993, pp 24-50.

[9] S. J. Tian, J. E. Rickard and J. M. V. Blanshard, "Physiochemical Properties of Sweet Potato Starch," Journal of Science of Food and Agriculture, Vol. 57, No. 4, 1991, pp. 459-491. doi:10.1002/jsfa.2740570402

[10] Z. Chen, H. A. Schols and A. G. J. Voragen, "Starch Granule Size Strongly Determines Starch Noodle Processing and Noodle Quality," Journal of Food Science, Vol. 68, No. 5, 2003, 1584-1589.

doi:10.1111/j.1365-2621.2003.tb12295.x
[11] L. S. Collado, R. C. Mabesa and H. Corke, "Genetic Variation in the Physical Properties of Sweet Potato Starch," Journal of Agriculture and Food Chemistry, Vol. 47, No. 10, 1999, pp. 4195-4201. doi:10.1021/jf990110t

[12] J. C. Bouwkamp, "Sweet Potato Products: A Natural Resource for the Tropics," CRC Press, Boca Raton, 1985, pp. $158-159$

[13] W. M. Walter Jr. and C. S. Palma "Effect of Long-Term Storage on Cell Wall Neutral Sugars and Galacturonic Acid of Two Sweet Potato Cultivars," Journal of Agriculture and Food Chemistry, Vol. 44, No. 1, 1996, pp. 278-281. doi:10.1021/jf950101u

[14] A. M. Garcia and M. W. Walter Jr., "Physicochemical Characterization of Starch from Peruvian Sweet Potato Selections," Starch/Stärke, Vol. 50, No. 8, 1998, pp. 331337.

doi:10.1002/(SICI)1521-379X(199808)50:8<331::AID-S TAR331>3.0.CO;2-J

[15] C. J. O'Connor, K. J. Fisk, B. G. Smith and L. D. Melton, "Fat Uptake in French Fries as Affected by Different Potato Varieties and Processing," Journal of Food Science, Vol. 66, No. 6, 2001, pp. 903-908. doi:10.1111/j.1365-2621.2001.tb15194.x

[16] A. Peshin, "Characterization of Starch Isolated from Potato Tubers (Solanum tuberosum L.)," Journal of Food Science and Technology, Vol. 38, No. 5, 2001, pp. 447 449.

[17] AACC, "Approved Methods of the AACC," 10th Edition, American Association for Clinical Chemistry, St. Paul, 2000.

[18] G. B. Crosbie, "The Relationship between Swelling Properties, Paste Viscosity and Boiled Noodle Quality in Wheat Flours," Journal of Cereal Science, Vol. 13, No. 2, 1991, pp. 145-150. doi:10.1016/S0733-5210(09)80031-3

[19] K. Jangchud, Y. Phimolsiripol and V. Haruthaithanasan, "Physicochemical Properties of Sweet Potato Flour and Starch as Affected by Blanching and Processing," Starch/ Stärke, Vol. 55, No. 6, 2003, pp. 258-264. doi:10.1002/star.200390053

[20] H. J. Bradbury and D. W. Holloway, "Effect of Cooking and Storage in Sweet Potato," Australian Center for International Agricultural Research, Canberra, 1988, pp. 103108

[21] A. E. Purcell and M. Walter Jr., "Stability of Amino Acids during Cooking and Processing of Sweet Potatoes," Journal of Agriculture and Food chemistry, Vol. 30, No. 3, 1982, pp. 443-444. doi:10.1021/jf00111a008

[22] W. M. Walter Jr., G. L. Catignani, L. L. Yow and D. H. Porter, "Protein Nutritional Value of Sweet Potato," Journal of Agriculture and Food Chemistry, Vol. 31, No. 5, 1983, pp. 947-949. doi:10.1021/jf00119a006

[23] W. M. Walter Jr. and G. L. Catignani, "Biological Quality and Composition of Sweet Potato Protein Fractions," No. 4, Journal of Agriculture and Food Chemistry, Vol. 29, 1981, pp. 797-799. doi:10.1021/jf00106a027

[24] H. M. Makki, A. Y. Abdel-Rahaman, M. K. M. Khalil and M. S. Mohammed, "Chemical Composition of Egyptian Sweet Potatoes," Food Chemistry, Vol. 20, No. 1, 
1986, pp. 39-44. doi:10.1016/0308-8146(86)90165-2

[25] S. N. Moorthy, "Physicochemical and Functional Properties of Tropical Tuber Starches: A Review," Starch/Stärke, Vol. 54, No. 12, 2002, pp. 559-592. doi:10.1002/1521-379X(200212)54:12<559::AID-STAR 2222559>3.0.CO;2-F

[26] L. Davies, "Starch-Composition, Modifications, Applications and Nutritional Value in Foodstuffs," In: D. J. Thomas and W. A. Atwell, Eds., Starches: Practica Guides for the Food Industry, Eagan Press, St. Paul, 1995, pp. 44-52.

[27] D. B. Wankhede and S. U. Sajjan, "Isolation and Physicochemical Properties of Starch Extracted from Elephant Foot Yam (Amorphophallus compalunatus)," Starch/Starke, Vol. 42, 1981, pp. 460-464.

[28] V. Rasper, "Investigation on Some Starches from Some West African Root Crops," Process International Symposium of Tropical Root Crops, Vol. 2, No. 6, 1967, pp. 6072.

[29] A. Bengtssona, A. Namutebib, A. M. Larsson and U. Svanberg, "Effects of Various Traditional Processing Methods on the All-Trans-b-Carotene Content of OrangeFleshed Sweet Potato," Journal of Food Composition and Analysis, Vol. 21, No. 2, 2008, pp. 134-143. doi:10.1016/j.jfca.2007.09.006

[30] L. M. K'osambo, E. E. Carey, A. K. Misra, J. Wilkes and V. Hagenimana, "Influence of Age, Farming Site, and Boiling on Pro-Vitamin A Content in Sweet Potato (Ipomoea batatas (L.) Lam.) Storage Roots," Journal of Food Composition and Analysis, Vol. 11, No. 4, 1998, pp. 305-
321. doi:10.1006/jfca.1998.0591

[31] L. A. Chandler and S. J. Schwartz, "Isomerization and Loss of Trans- $\beta$-Carotene in Sweet Potato as Affected by Processing Treatments," Journal of Agriculture and Food Chemistry, Vol. 36, No. 1, 1988, pp. 129-133. doi:10.1021/jf00079a033

[32] J. M. Johnson, E. A. Davis and J. Gordon, "Interactions of Starch and Sugar Water Measured by Electron Spin Resonance and Differential Scanning Calorimetry," Cereal Chemistry, Vol. 67, No. 3, 1990, pp. 286-291.

[33] M. M. Bean and W. T. Yamazaki, "Wheat Starch Gelatinization in Sugar Solutions," Cereal Chemistry, Vol. 55, No. 6, 1978, pp. 936-944.

[34] W. Prinyawiwatkul, K. H. McWatters, L. R. Beuchat and R. D. Phillips, "Functional Characteristics of Cowpea (Vigma unguiculata) Flour and Starch as Affected by Soaking, Boiling, and Fungal Fermentation before Milling," Food Chemistry, Vol. 58, No. 4, 1997, pp. 361-372. doi:10.1016/S0308-8146(96)00259-2

[35] Anonymous, "Applications Manual for the Rapid Visco Analyser" Newport Scientific Pty. Ltd., Warriewood, 1998, pp. 40-46.

[36] O. R. Fennema, "Food Chemistry," 3rd Edition, Marcel Dekker, Inc., New York, 1996, p. 505.

[37] R. Hoover, "Composition, Molecular Structure, and Physicochemical Properties of Tuber and Root Starches: A Review," Carbohydrate Polymer, Vol. 45, No. 3, 2001, pp. 253-267. doi:10.1016/S0144-8617(00)00260-5 